DOI: 10.20472/TEC.2019.008.023

JING QIAN

Nanjing University of Aeronautics \& Astronautics, China

\title{
AN EMPIRICAL STUDY ON ONLINE READING AND INCIDENTAL VOCABULARY ACQUISITION
}

\begin{abstract}
:
Vocabulary learning is very important for $L 2$ learners, and researchers have agreed that some of L2 learners' vocabulary is acquired incidentally. Extensive reading is an effective way to achieve incidental vocabulary acquisition. With college English teaching reform being carried out, the teaching mold has changed from teacher-centered to learner-centered. The new model should be built on modern information technology, particularly network technology. With the spring up of Internet-based L2 learning, the author is curious about whether online reading is better than common reading in terms of incidental vocabulary acquisition. After an experiment, the author analyses data and draws a conclusion that online reading can help the L2 learners have more IVA and teaching strategies have influence on students' IVA from online reading.
\end{abstract}

\section{Keywords:}

online reading; incidental vocabulary acquisition; teaching 


\section{Introduction}

\section{Background}

In recent years computer has established itself as an important feature of modern life. The Internet, also known as cyberspace, the information superhighway, the online community, the electronic library and the digital revolution, promises dramatic changes in the way we learn and teach, and the way we interact. The changes of a coming epoch are already taking shape. In higher education, the web technology has reformed the concept of education around the world in the past few years, and language learning via the Internet is already with us. Besides, almost all the universities have built Local Area Network which connects all the computers in the universities, realizing the common share of the campus resources. On the other hand, because of the rapid advancement of higher education and remarkable increase in student enrollment, most universities in China are confronted with heavy lack of English teachers, big classes of more than 100 students with multi-leveled language ability, leading higher education to greater reliance on network technology. Therefore, China's Ministry of Education has drawn up the College English Curriculum Requirements (2004: 5), encouraging students' autonomous learning and the use of the Internet technology in college English education: "Colleges and universities should remold the existing unitary teacher-centered pattern of language teaching by introducing new teaching models with the help of multimedia and network technology. The new model should be built on modern information technology, particularly network technology, so that English language teaching will be free from the constraints of time or place and geared towards students' individualized and autonomous learning".

Since 1999, our university, Nanjing University of Aeronautics and Astronautics, has carried out a reform on English teaching for non-English major undergraduates. For the new coming students, they will be divided into three different bands according to their academic scores in English Placement Test which is held at the very beginning after their entry to the university. For the top 500 students, they are in Band Three (the highest level), for the following 750 students, they are in Band Two (the intermediate level), and the rest 1500, they are in Band One (the lowest level). All students have two kinds of English courses: comprehensive English on one level, and listening and speaking on the other level. Students are required to study lessons online before having classroom lectures.

\section{Motivation for the Study}

The importance of vocabulary has been pointed out by a famous linguist, Wilkins(1972:111):"Without grammar very little can be conveyed, without vocabulary nothing can be conveyed." No text comprehension is possible without understanding the text's vocabulary either in one's native language or in a foreign language, although reading comprehension is also affected by other factors. As a result, vocabulary teaching becomes one of the major parts of domestic L2 classroom teaching.

"What is generally agreed upon is that at least some, if not a large part, of one's second language vocabulary is acquired incidentally - that is, as a by-product of other cognitive exercises involving comprehension. Chief among these is reading, although listening is also implicated."(Gass, 1999: 319) Therefore, college English teachers always suggest learners to read extensively to naturally and incidentally acquire vocabulary by reading newspaper, magazines, and on-line resources.

With the spring up of Internet-based L2 learning, the author is curious about whether online reading is better than common reading in terms of incidental vocabulary acquisition.

\section{Incidental Vocabulary Acquisition (IVA)}

Nagy, Herman and Anderson(1985)first proposed the concept of "Incidental Vocabulary Acquisition" through the observation and experiment on children's mother-tongue vocabulary acquisition. They found 
that it is impossible to learn the mother-tongue vocabulary only by intentional learning. On the contrary, the majority of mother-tongue vocabulary is incidentally acquired through reading.(Jinhong Qin, 2008: 9)

We all know that there are two different approaches to L2 vocabulary learning. One is the direct or intentional learning; the other is the indirect or incidental learning. In direct vocabulary learning, the learners do exercises and activities that focus their attention on vocabulary. Such exercises include word-building exercise, guessing words from context when this is done as a class exercise, learning words in lists, and vocabulary games. In indirect (incidental) learning, the learner's attention is focused on some other feature, usually the message that is conveyed by a speaker or a writer(Nation,1990: 2-3).

However, researchers do not always have agreed upon the definition of "Incidental L2 Vocabulary Acquisition". One of the difficulties in coming up with a good definition of incidental learning arises from the fact that there is no way to show that a given word was incidentally learned. The American Heritage Dictionary of English Language defines incidental as "occurring as a fortuitous or minor concomitant." In other words, it appears to be something that is a by-product of something else.(Gass, 1999: 320)

Wode(1999: 245)is the most specific about the definition of incidental: "language learning as a by-product of language use by the teacher or anybody else in the classroom, without the linguistic structure itself being the focus of the attention or the target of teaching maneuvers". Huckin and Coady(1999: 182) presented a similar definition when talking about secondary learning: "a by-product, not the target, or the main cognitive activity, reading." Joe(1998) also posed that incidental vocabulary acquisition means acquiring words when learners' attention is not on words but the context, which is a very affective approach to acquiring words. For instance, intermediate and advanced English learners may read extensively for pleasure or to fulfill a particular purpose, and in the process of such activities, they may "pick up" some new words. And this way of "picking up" words are termed incidental vocabulary acquisition, as the acquisition of the words is only a by-product of another main cognitive activity(Hulstijn, 2001). At the operational level, the two prerequisites to incidental learning are:1) the primary concern of the participants is with comprehending the text rather than learning the target words, and 2) the participant's attention is directed to the completion of the orienting tasks rather than to the target lexical items. (Xiayan Lu, 2008: 8).

\section{Research Methodology}

\section{Objectives}

This study investigates how the Internet-based L2 learning affects the learners' IVA and the words retention. The purpose of this study is to identify

(1) Whether the Internet-based reading help the L2 learners have more IVA?

(2) Whether teaching strategies have influence on students' IVA from online reading?

\section{Research Design}

\subsection{Questionnaire}

For effective, applicable and practical Internet-based L2 learning methods in the college, after the immediate vocabulary test, the experiment group will be asked to finish a questionnaire to tell about:

1) The factors affecting the passage understanding;

2) The factors benefiting their words retention;

\subsection{Experiment}




\section{Subjects}

The subjects are two classes of 40 students respectively enrolled in Nanjing University of Aeronautics and Astronautics in Summer 2009 semester. They are all non-English majors of the same age range.

\section{Pretest}

To make the scores of different subjects' groups comparable, the subjects are chosen according to a pretest which is called the Placement Test taken before freshmen having English classes in NUAA. The pretest consists of listening, vocabulary and structure, reading comprehension, and writing. The two classes of subjects have similar test results and the same beginning English proficiency, belonging to band one (the lowest level).

\section{Experiment materials}

According to Nation (1990) and Laufer (1997), general text comprehension requires prior knowledge of at least $95 \%$ of the words in a text. For the validity of the test, the author chooses one passage with 835 words, containing 10 target words. The target reading article is The Standard for Olympic Excellence-Text B in Unit 2 from New Horizon College English 2. In addition to the textbook in print, New Horizon College English has an Internet version, which is convenient for students to learn English online.

To make sure that all the subjects do not know the 10 target words, the author first selects 20 new words from the passage with the help of two experienced English teachers, and asks students of another band one class, who do not take part in this experiment, to have a word test. According to the word test results, there are 14 new words that none of the students know. Then, 10 target words are carefully chosen from the 14 new words.

\section{Experiment process}

Step one: Before the experiment, two classes of subjects are given a lecture of the similar topic by the same teacher in the classroom, learning Text A-Learning the Olympic Standard for love.

Step two: One class of the subjects as the experiment group reads the target article from the Internet while the other class as the reference group reads the target article on textbook in the classroom. After reading the target article, both groups should finish the reading comprehension exercise attached to the article. In reading, all subjects, to understand the article, can turn to available learning assistance like dictionaries, teachers, desk mates, mobile phones and the Internet resources. The total reading time is 20 minutes.

Step three: After finishing their reading comprehension task, subjects of the two groups receive at the same time the paper of the immediate exposure test concerning the 10 target words and are asked to finish the paper in ten minutes. They should not consult the dictionary or discuss the answer with each other; and they had to sign their names on the test paper. To ensure the subjects wouldn't compare the content of the test with that of the other test a week later, another 4 words were added in the test to interfere the subjects' possible intentional retention of the target words.

Step four: The same test is carried out one week after the immediate exposure test. To exclude the memory of the specific words order, target words are re-arranged. The subjects are requested to finish this test in 10 minutes.

\subsection{Data analysis}

The test form and scoring method are based on the Vocabulary Knowledge Scale by Wesche \& Paribakht (1996) with some adaptation (Shiping Duan et al, 2004: 215), shown in the following tables.

(Table 1: vocabulary knowledge scale) 


\begin{tabular}{|c|l|}
\hline Scale & \multicolumn{1}{|c|}{ Meaning } \\
\hline$(1)$ & I don't remember I have seen this word before. \\
\hline$(2)$ & I have seen this word before, but I don't know its meaning. \\
\hline (3) & $\begin{array}{l}\text { When seeing this word in the article, I guess this word means } \\
\text { (synonym or Chinese version) }\end{array}$ \\
\hline (4) & I can use this word to make a sentence, for example \\
\hline
\end{tabular}

(Table 2: scoring method)

\begin{tabular}{|c|c|c|l|}
\hline Scale & & Score & \multicolumn{1}{|c|}{ Score Meaning } \\
\hline$(1)$ & $\longrightarrow$ & 0 & I am not familiar with this word. \\
\hline$(2)$ & $\longrightarrow$ & 1 & I am familiar with this word, but I don't know its meaning. \\
\hline$(3)$ & $\longrightarrow$ & 2 & Write down a correct synonym or Chinese version. \\
\hline$(4)$ & 3 & $\begin{array}{l}\text { Use this word to make a semantically and grammatically } \\
\text { correct sentence. }\end{array}$ \\
\hline
\end{tabular}

Due to the requirements of the experiment, the author cannot inform students that they are going to have two word tests. Therefore, some students are absent from either the immediate vocabulary test or the delayed vocabulary test. In the end, there are 63 valid test papers, 32 in experiment group and 31 in reference group.

After the experiments, the author have marked the test papers and analyzed the scores with SPSS 13.0 to examine the effects of Internet-based L2 learning on the learners' IVA. The results are shown in table 3 and table 4 .

(Table 3: Group Statistics)

\begin{tabular}{|c|c|c|c|c|c|}
\hline & group & $\mathrm{N}$ & Mean & $\begin{array}{c}\text { Std. } \\
\text { Deviation }\end{array}$ & $\begin{array}{c}\text { Std. Error } \\
\text { Mean }\end{array}$ \\
\hline \multirow[t]{2}{*}{$\begin{array}{l}\text { Immediate } \\
\text { test result }\end{array}$} & $\begin{array}{l}\text { Experiment } \\
\text { group }\end{array}$ & 32 & 10. 2188 & 4. 29354 & .75900 \\
\hline & $\begin{array}{l}\text { Reference } \\
\text { group }\end{array}$ & 31 & 10. 1935 & 3. 19812 & .57440 \\
\hline \multirow[t]{2}{*}{$\begin{array}{l}\text { Delayed test } \\
\text { result }\end{array}$} & $\begin{array}{l}\text { Experiment } \\
\text { group }\end{array}$ & 32 & 11.7500 & 2. 77082 & .48982 \\
\hline & $\begin{array}{l}\text { Reference } \\
\text { group }\end{array}$ & 31 & 11.1290 & 3. 43261 & .61651 \\
\hline
\end{tabular}

(Table 4: Independent Samples Test)

\begin{tabular}{|l|l|l|}
\hline & $\begin{array}{c}\text { Levene's Test } \\
\text { for Equality } \\
\text { of Variances }\end{array}$ & t-test for Equality of Means \\
\hline
\end{tabular}




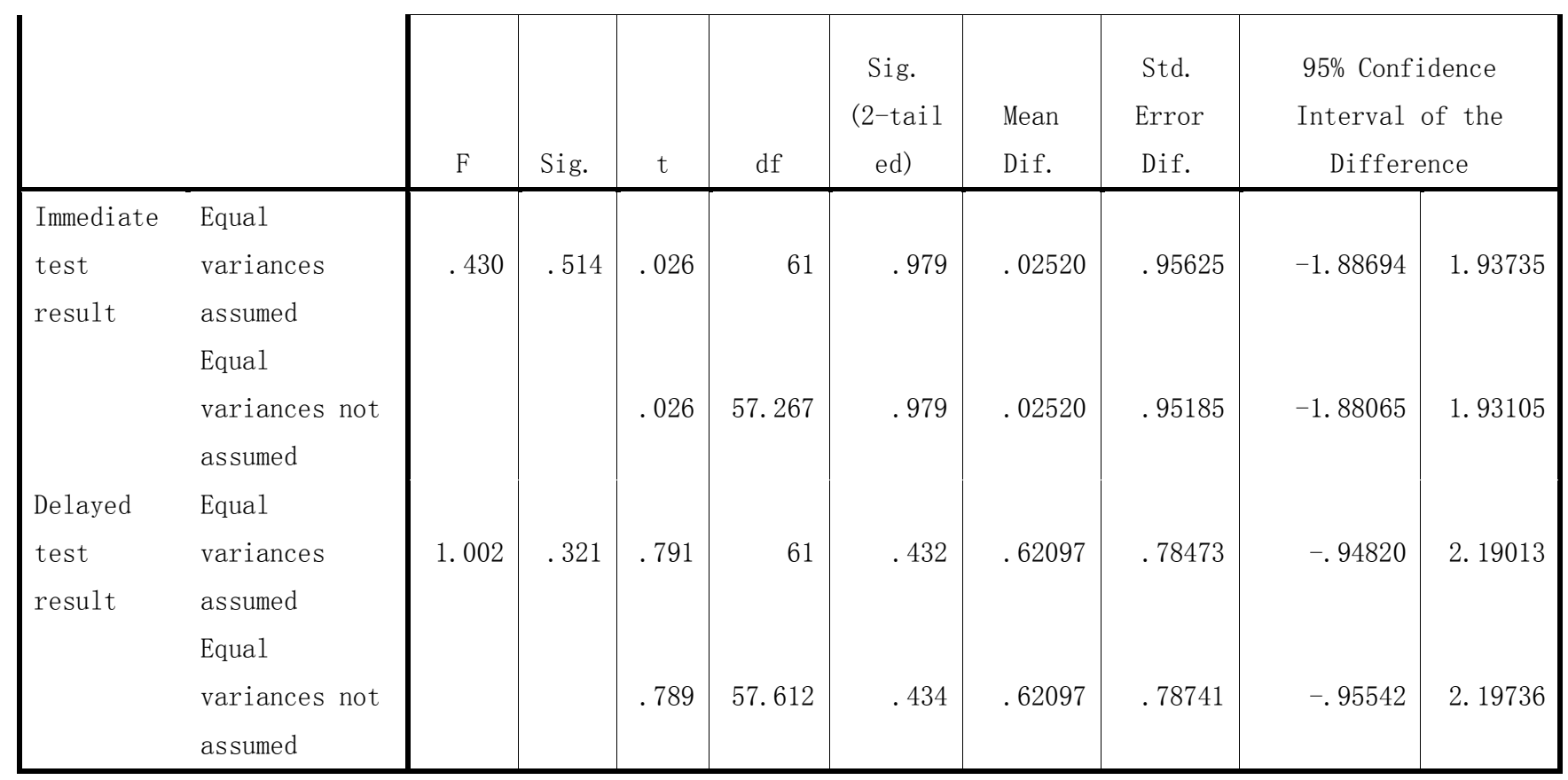

\section{Results and Discussion}

The subjects are tested for the recall of the target words immediately after finishing their reading comprehension task and for retention one week later. The immediate test, delayed test assess the subjects' incidental vocabulary acquisition and retention.

Table 3 shows that on the immediate test, experiment group has higher mean score $(M=10.2188)$ than reference group ( $M=10.1935)$. On the delayed test, mean score of the experiment group $(M=11.7500)$ is still higher than the reference group's $(\mathrm{M}=11.1290)$.

Table 3 indicates that incidental vocabulary learning during reading does occur and the Internet-based reading help the L2 learners have more IVA. We also can find that both groups have better word knowledge over the course of one week. Normally, subjects should lose some word knowledge since there are no further exposures to reinforce the gained word knowledge. To this strange situation, the author has asked students for the reason. The reason is that many students are used to recite new words on their textbooks because they often have word dictation on their English classes. So many subjects, if not all, have learned the target words intentionally after the immediate word test.

However, in table 4, Sig. (2-tailed) for immediate test is 0.979, and Sig. (2-tailed) for delayed test is 0.432. In addition, $95 \%$ confidence interval of the difference for immediate test is between -1.88694 to 1.93735; while the number for delayed test is between -0.94820 to 2.19013 . With Sig. (2-tailed) $>0.05$ and $95 \%$ confidence interval of the difference including 0 , these figures mean there is no significant difference between the scores of experiment group and that of reference group. This may be caused by the fact that except the reading comprehension task, the author doesn't assign other tasks that can exert the advantages of Internet--instant glossing, multimedia environment, reference library, interaction to increase the word exposure frequency - that can help achieve IVA.

According to the questionnaire taken by the experiment group after the immediate vocabulary test, students all agree that dictionaries and electronic dictionaries online help them understand the passage; most of the students admit reading online and exercise after reading can partly benefit their words retention; and for words retention method, students frequently mention recitation, repeated emergence, writing, and making sentences. 


\section{Conclusion and Pedagogical Implications}

It can be concluded that the Internet-based reading help the L2 learners have more IVA and teaching strategies have influence on students' IVA from online reading. For better IVA from extensive reading online, teachers should set appropriate tasks to stimulate students' autonomy and initiative, and encourage students to make full use of Internet resources. For word acquisition, intentional learning is still a very effective method. So, it is urgent for the college English teachers to arouse the learners' interests in the vocabulary learning strategies, to enable the learners to employ the Internet consciously and to combine the learners' Internet-learning with classroom teaching.

\section{Limitations}

Needlessly to say, the present investigation is far from being perfect in the real academic sense. Firstly, the subjects of this research are confined to one grade in NUAA--only one type of L2 learners. Other types of English learners may have quite different results. Besides, the relatively small size of participants is also a factor that affects the validity of the study.

\section{References}

[1] Gass, S. Discussion Incidental Vocabulary Learning [J]. Studies in Second Language Acquisition 1999(21): 319-333.

[2] Huckin, T.\& Coady, J. Incidental vocabulary acquisition in second language: a review [J]. Studies in Second Language Acquisition 1999(21): 181-193, 225-241

[3] Hulstijin, J. H. Intentional and incidental second language vocabulary learning: A reappraisal of elaboration, rehearsal and automaticity [C]. In P. Robinson (Ed.), Cognition and Second Language Instruction. Cambridge: Cambridge University Press, 2001: 258-286.

[4] Joe, A. What effects do text-based tasks promoting generation have on incidental vocabulary acquisition? [J]. Applied Linguistics 1998(19): 357-377.

[5] Laufer, B. The lexical plight in second language reading: words you don't know, words you think you know, and words you can't guess [C]. In Coady, J. \& Huckin, T. (Ed.), Second Language Vocabulary Acquisition: A rationale for pedagogy. Cambridge: Cambridge University Press, 1997: 20-34.

[6] Nagy, W., Herman, P., \& Anderson, R.. Learning Words from Context [J]. Reading Research Quarterly 1985(20): 2, 233-253.

[7] Nation, I. S. P. Teaching \& Learning Vocabulary [M]. New York: Newbury House, 1990.

[8] Wilkins, D.A. Linguistics in Language Teaching [M]. London: Melbourne Auckland, 1972.

[9] Wode, H. Incidental vocabulary acquisition in the foreign language classroom [J]. Studies in Second Language Acquisition 1999(21): 243-258.

[10] Shiping Duan. \& chensong Yan. The Effect of Multiple Choice Annotation on Incidental Acquisition of English Vocabulary[J]. Foreign Language Teaching and Research, 2004(3): 213-218.

[11] Higher Education Division of the Ministry of Education. College English Course Teaching Requirements [M]. Beijing: Foreign Language Teaching and Research Press, 2004.

[12] Xiayan Lu. Second Language Incidental Vocabulary Acquisition in College Students' Online English Self-reading [D]. Shanghai: Shanghai International Studies University, 2008. 
[13] Jinhong Qin. An Empirical Study of Vocabulary Incidental Acquisition in College English Extensive Reading [D]. Jilin: Jilin University, 2008. 